\title{
Sustainable Use of Organic Solid Waste: approach to a model developed by Waste Picker Organizations. Case Study, Bogotá D.C., Colombia
}

\author{
Sandoval Duarte, Ángela ${ }^{1}$, Segura Osuna, Jenny Alexandra² and Rodríguez Miranda, Juan Pablo ${ }^{3}$ \\ ${ }^{I}$ Estudiante de maestría en Desarrollo Sustentable y Gestión Ambiental. Facultad del Medio Ambiente y Recursos Naturales. \\ Universidad Distrital Francisco José de Caldas. Bogotá, Colombia. \\ ${ }^{2}$ Docente de investigación tiempo completo. Corporación Universitaria Minuto de Dios, UNIMINUTO. Bogotá, Colombia. \\ ${ }^{3}$ Profesor Titular. Grupo de Investigación AQUAFORMAT. Facultad del Medio Ambiente y Recursos Naturales. Universidad \\ Distrital Francisco José de Caldas. Bogotá, Colombia.
}

ORCIDs: 0000-0003-3008-6135 (Jenny Alexandra), 0000-0002-3761-8221 (Juan Pablo)

\begin{abstract}
In practice, there are many unknown aspects to design a model for the use of organic solid waste in the city of Bogotá; Technical, financial, environmental and social aspects are necessary to obtain a sustainable use model that involves trade recyclers organizations picker organizations. For this research, a theoretical model was proposed using secondary information sources and international reference experiences. Also shown at level of Latin America, studies that have been conducted on composting and other applications that can be given to solid organic waste.

Based on the model, a series of strategies were generated so that recyclers by trade could access and take advantage of organic waste produced in homes and other generators. One of the strategies consisted of generating a comprehensive management plan for organic solid waste that included: generation of organic waste, separation at the source, collection, transport and use with composting and vermiculture systems. With these tools was carried out a pilot test of the model in operation, in a vulnerable area adjacent to the city landfill. There, the model was applied with an organization of waste pickers and 200 houses in four neighborhoods. The waste separated at the source by the 200 houses were characterized, collected and transported by the recyclers' organization to a treatment plant where they were transformed through composting and vermiculture processes into organic compost and vermicompost fertilizers. In the follow-up process, the response of both the recyclers and the 200 families to the model in operation was evaluated.
\end{abstract}

Keywords: recyclers by trade, use, sustainability, organic waste.

\section{INTRODUCTION}

In Latin America, waste management has prevailed under the "collection and final disposal" scheme, leaving behind the use, recycling and treatment of waste (AIDIS-IDRC, 2006). In several countries in the region, landfills are still used and the practice of collecting without classification and/or separation at the source continues (Sáez \& Urdaneta, 2014). Additionally, the lack of infrastructure for processing organic waste has forced most of it to be sent to landfills, generating a series of negative environmental impacts.

In the city of Bogotá, according to the special administrative unit of public services (UAESP, 2017), approximately 6,300 tons of solid waste are produced every day, of which $55.22 \%$ corresponds to organic solid waste. The main management that has been given to this type of waste consists of the collection, transportation and burial in a sanitary landfill, where these wastes not only lose the potential to be used, additionally to this, as they are disposed of in landfills (Sáez \& Urdaneta, 2014), lose the potential to be exploited and generate a number of negative environmental impacts on populations and the environment that are close to these disposal sites (Giinther, et al., 2016).

The Doña Juana sanitary landfill is located in the town of Ciudad Bolívar near Mochuelo Alto and Mochuelo Bajo neighborhoods and was designed to treat all types of solid waste, including hospital waste. Its extension is 623 hectares, which receives daily about 6,368 tons of waste per day, which is equivalent to a total of 194,000 tons per month, not only of waste from the city of Bogotá, also receives waste from other municipalities such as Cáqueza, Choachí, Chipaque, Fosca, Gutiérrez, Ubaque and Une. The next image taken from the UAESP (2020), shows the internal distribution of the landfill: 


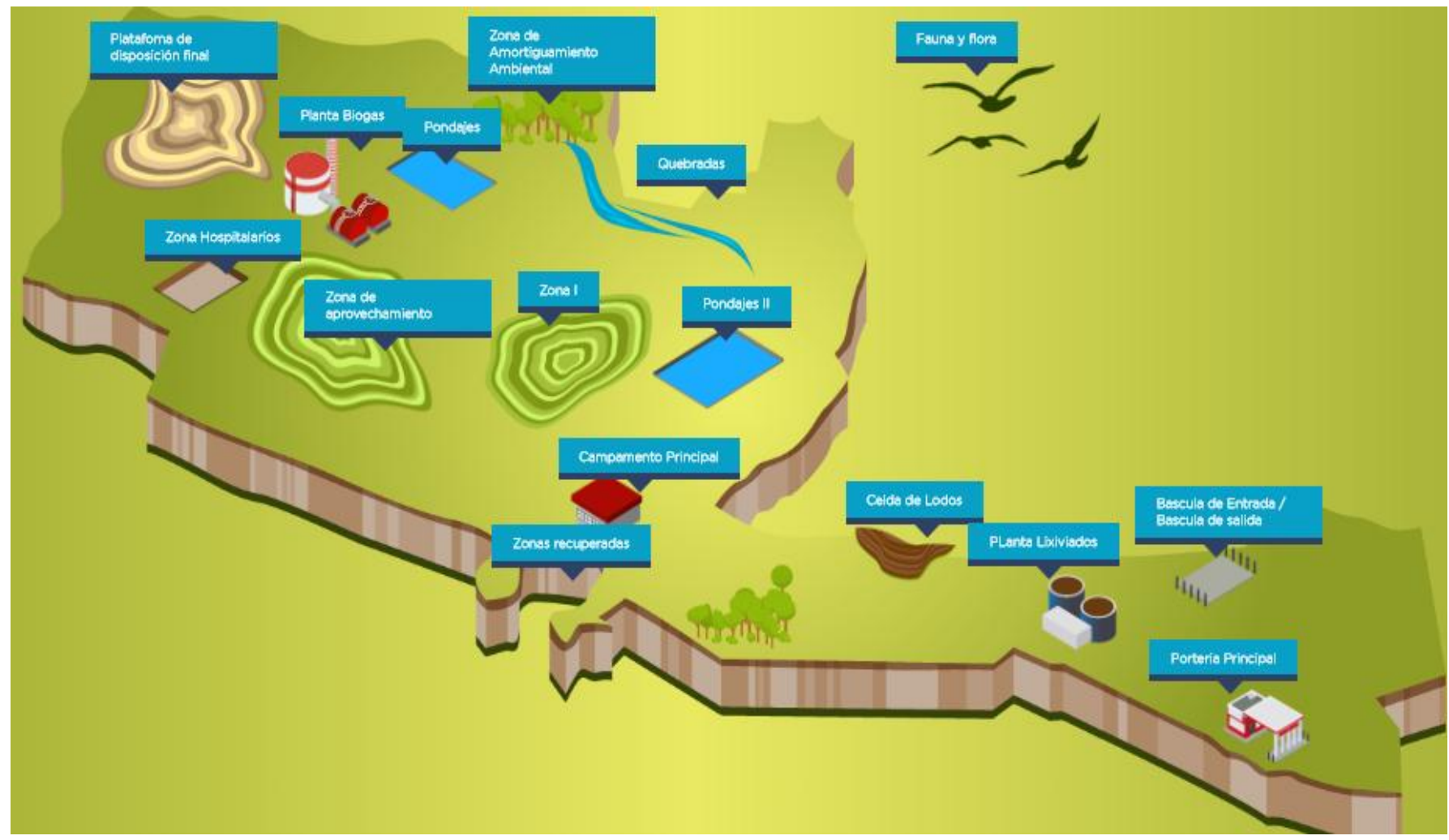

Source: Special Administrative Unit of Public Services UAESP (2020)

Currently, this sanitary landfill is going through a crisis that generates an emergency since the last April 28 there was a landslide generated by a fissure, which caused many inhabitants of the sector to report a higher level of bad odors, which puts their health at risk, for which the UAESP is already taking the corresponding actions to the case, (El tiempo, 2020). Taking into account the above, especially the high volume of waste that arrives there daily, it is necessary for citizens to become aware and begin to have a recycling culture.

Due to its location, the Doña Juana sanitary landfill does not obey a planned decision, was instead the result of the imposition of private interest on the general. Given the location of this sanitary landfill in the town of Ciudad Bolívar, which in a large percentage is located in rural areas, with water springs, in the city itself many inhabitants of the sector have been affected by odors and the generation of diseases, especially in children and the elderly, therefore, in the future, the convenient location for the community should be evaluated through land use plans. Likewise, it is identified that not only in Colombia but in other Latin American countries where particular interests have prevailed, (Quintero, 2016).

In the case of organic waste produced in the cities of Colombia, these represent about $70 \%$ of the total, as indicated by Penagos, Adarraga, Aguas and Molina (2011), so it is important to take advantage of this waste in order to minimize environmental impacts, given the high degree of urbanization that cities have had in recent decades. These authors point out that said waste can be used as compost, but taking care that it does not have a high degree of salinity, does not lose the nutrients and organic matter that when used in crops and gardens gives good results.
In this regard, the organic solid waste management sector contributes to the anthropogenic greenhouse effect, mainly through carbon dioxide emissions $\left(\mathrm{CO}_{2}\right)$, methane $\left(\mathrm{CH}_{4}\right)$ and nitrous oxide $\left(\mathrm{N}_{2} \mathrm{O}\right)$; These become an important source of greenhouse gases (IPCC, 2006) , in addition, since they are the ones with the highest generation volume, they quickly saturate the landfills, generate leachates that carry dangerous elements such as heavy metals present in other residues, which generates contamination of the water (surface and underground), soil and landscape, as well as the proliferation of vectors and the emanation of offensive odors that generate a deterioration in the environmental quality of the people who inhabit the areas surrounding these final disposal sites (Secretaría Distrital de Ambiente, 2017 y POMCA Tunjuelo, 2009).

The new world panorama points to more nations joining in to encourage initiatives that decrease pressure on natural resources, mitigate the production of greenhouse gases and generate new products from the use of waste. It is therefore essential to reverse the logic of discarding waste by a model where it is reused and valued (Lett, 2014). Taking into account that in Bogotá there are approximately 13,700 recyclers by trade (UAESP, 2014), who obtain their livelihood through the collection and sale of recyclable materials, integrating these organizations into formal organic solid waste management systems can present a number of challenges and opportunities.

His work can improve the performance of the system and contribute to environmental sustainability, in addition to improving living conditions and dignifying the work of 
recyclers of trade (Cohen et to the., 2013) becoming part of the solution within a model that favors the use of production, transport and landfill, recognition materialized in organizational and business promotion, as well as adequate remuneration, which transform and to an extent "structural" for organizations recyclers, exceed the conditions of poverty and vulnerability (Parra, 2015) and points to a more sustainable and inclusive for waste management of solid organic model in the city of Bogotá.

\section{DEVELOPING}

The first part of the study consisted of the construction of a theoretical model, in which variables were selected that were presented as relevant for the implementation of a model for the sustainable use of organic solid waste that included the organizations of recyclers by trade in the city of Bogotá. Through the search for information in secondary sources, variables of type: technical, social, environmental and economic were chosen, which were presented as relevant for the generation of the model.
The case study was carried out in the town of Ciudad Bolívar, in 4 neighborhoods adjacent to the Bogotá landfill. The study was carried out with an organization of trade recyclers from the area, with which the comprehensive management scheme was implemented, involving 200 families, who voluntarily participated in separating the organic waste produced in their homes at the source.

These 4 neighborhoods were chosen because they were the ones who were found closest to the landfill where they have currently waste of the city, and also because he found in rural area allowed to establish treatment plants and/or utilization; it had an organized recyclers organization with an interest in participating in the research. Furthermore, this area allowed obtaining information on the perceptions of the population that lived near the sanitary landfill.

In table 1, the steps that were developed to implement the comprehensive management plan can be observed, where it was analyzed from the generation of waste in the 200 homes to its transformation into fertilizers through composting and vermiculture systems.

Table 1. Description of the proposed comprehensive management scheme

\begin{tabular}{|c|c|c|}
\hline Stage & Description & Process \\
\hline Sensitization & $\begin{array}{l}\text { Corresponded to the sensitization } \\
\text { of families who separated organic } \\
\text { waste in the } 4 \text { impacted } \\
\text { neighborhoods }\end{array}$ & $\begin{array}{l}\text { A socialization event was held, where families were explained } \\
\text { how organic waste should be separated at the source and } \\
\text { permanent training was carried out during the collection routes } \\
\text { by waste pickers during the development of the case study. }\end{array}$ \\
\hline $\begin{array}{l}\text { Separation at the } \\
\text { source }\end{array}$ & $\begin{array}{l}\text { Corresponded to the separation at } \\
\text { the source of the organic waste } \\
\text { generated by the families }\end{array}$ & $\begin{array}{l}\text { Tanks of different sizes were delivered to them and a primer was } \\
\text { designed indicating how to separate organic waste at the source. }\end{array}$ \\
\hline $\begin{array}{l}\text { Waste } \\
\text { characterization }\end{array}$ & $\begin{array}{l}\text { Physicochemical characterization } \\
\text { and quantification of the residues } \\
\text { generated by the families were } \\
\text { carried out }\end{array}$ & $\begin{array}{l}\text { The weights of the cans collected house-to-house were recorded } \\
\text { in formats each time the collection route was carried out and a } \\
\text { physical-chemical characterization was carried out in the } \\
\text { laboratory. }\end{array}$ \\
\hline $\begin{array}{l}\text { Selective collection } \\
\text { route (Door to door } \\
\text { collection) }\end{array}$ & $\begin{array}{l}\text { Selective collection was carried } \\
\text { out to collect the separated waste at } \\
\text { the source }\end{array}$ & $\begin{array}{l}\text { Frequencies, schedules and selective collection routes for } \\
\text { organic waste were established in the } 4 \text { neighborhoods where } \\
\text { the case study was developed. }\end{array}$ \\
\hline $\begin{array}{l}\text { Transport of waste to a } \\
\text { harvesting plant }\end{array}$ & $\begin{array}{l}\text { A collection route was established } \\
\text { that took the waste to a harvesting } \\
\text { plant }\end{array}$ & $\begin{array}{l}\text { A system of micro and macro routes was carried out in the } \\
\text { neighborhoods where the research was carried out (a frequency } \\
\text { of } 3 \text { times a week was established between } 3 \text { and } 5 \text { in the } \\
\text { afternoon) }\end{array}$ \\
\hline Waste transformation & $\begin{array}{l}\text { Treatment was carried out through } \\
\text { composting and vermiculture } \\
\text { methodologies }\end{array}$ & $\begin{array}{l}\text { A space that met the technical requirements for the treatment of } \\
\text { organic waste through composting and vermiculture } \\
\text { methodologies was adapted and monitoring of the degradation } \\
\text { processes was carried out to obtain compost and vermicompost } \\
\text { organic fertilizers. }\end{array}$ \\
\hline
\end{tabular}


International Journal of Engineering Research and Technology. ISSN 0974-3154, Volume 13, Number 8 (2020), pp. 2067-2080

(C) International Research Publication House. https://dx.doi.org/10.37624/IJERT/13.8.2020.2067-2080

\section{Case study}

The case study was divided into two phases: one that corresponded to the characterization and diagnosis of the waste pickers association with which we worked, the analysis of the population characteristics and infrastructure of the roads and the configuration of the neighborhoods for the establishment of routes and frequency of waste collection. The other phase corresponded to put the model into operation by evaluating the response of the organization and recipient's collection route.

The case study began with a diagnosis of the organization with which works, where organizational, social and financial aspects were characterized. In addition, a series of trainings were carried out on topics related to separation at the source, selective collection routes and waste transformation through composting and vermiculture methodologies. The state of the roads and the configuration of the neighborhoods were also analyzed.

The characterization of the population of the 4 neighborhoods that participated in the case study was also carried out through a perception survey. They asked about the environmental impacts they perceived from the sanitary landfill; if they had developed diseases due to living near it, they asked about the separation habits in the waste source; It was also asked about the socioeconomic and educational level, age and gender, as well as aspects of housing, tenure or property, its location and whether or not it had certain public services, among others. At the end they were asked if they would be willing to participate in the project.

Home visits by recyclers for collecting a database of homes willing to participate in the proposed use of organic waste were made. Participating families were provided with 30 and 60-liter plastic trash cans with lids, marked with the frequencies and times established for the collection routes, exclusively for the separation of organic waste. The 200 participating homes were requested to deposit organic waste of crude origin and not to use a plastic bag.

For the sensitization component, a booklet was designed to teach participating families how to separate organic waste. In this publication, special relevance was given to the environmental and social benefits derived from their use by recyclers' organizations that were in capacity to take advantage of them.

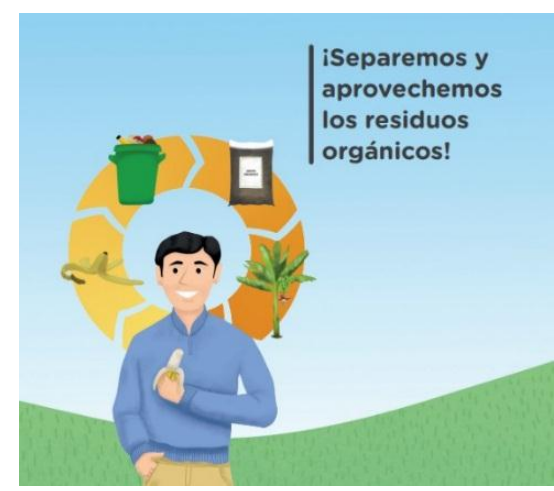

Figure 1. Cover of the generated primer to carry out the separation at the source of the organic waste delivered to the community. (Source: Self made)

\section{RESULTS}

The implementation of the scheme integrated management began with the raising of the 200 participating households, the booklet with the step-by-step guide was delivered to these homes to a right separation at the source, doubts were clarified and stressed their participation as actor's keys to the process. The generators were asked that the waste be of crude origin exclusively and delivered without bag under the socialized conditions.

The collection scheme that was implemented corresponded to a door-to-door collection system, where uniformed and identified recyclers went through each of the 200 homes, collecting the properly separated waste. For its transportation, a micro-route scheme was carried out where pairs of recyclers approached each of the homes distributed in the neighborhoods and an additional route to the city's central supply.

Collection frequencies and times were agreed between the participating homes and the waste pickers association, where a collection frequency of three times per week was established. Subsequently, the waste was deposited in collection carts that each pair handled and the data on the weight of the cans was recorded in formats designed for this purpose, each pair subsequently collected and transported the waste to the harvesting plant as shown in Figures 2, 3 and 4.

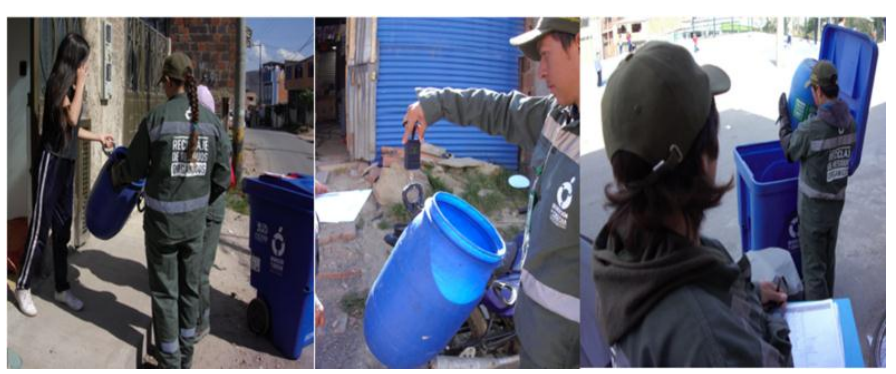

Figures 2, 3 and 4 correspond to the collection of the separated waste at the source.

\section{Harvesting plant}

Once the waste separated at the source was taken to the harvesting plant, the treatment of the waste was started through composting and vermiculture technologies. Therefore, and in order to guarantee an adequate carbon/nitrogen ratio, it was necessary to obtain other organic residues in addition to those of the home collection routes with which the mixtures could be made. This waste was sought to be generated near the harvesting plant to reduce transportation costs. Being able to obtain bovine from the milk production systems of the area, pruning grass from some nearby farms, horse and paper pulp.

Laboratory analyzes were carried out to characterize the collected residues, evaluating physicochemical parameters. The collected organic waste samples were handled in triplicate to arrive at a standard value as shown in Table 2. 
International Journal of Engineering Research and Technology. ISSN 0974-3154, Volume 13, Number 8 (2020), pp. 2067-2080

(C) International Research Publication House. https://dx.doi.org/10.37624/IJERT/13.8.2020.2067-2080

Table 2. Composition of the organic waste with which we worked

\begin{tabular}{|c|c|c|c|c|c|c|c|c|}
\hline $\begin{array}{l}\text { MEASURED } \\
\text { PARAMETER }\end{array}$ & $\begin{array}{c}\text { Sample } \\
\text { organic waste } \\
\text { (Mochuelo } \\
\text { bajo) }\end{array}$ & $\begin{array}{l}\text { Sample organic } \\
\text { waste } \\
\text { (Mochuelo bajo) }\end{array}$ & $\begin{array}{c}\text { Sample } \\
\text { organic waste } \\
\text { (Corabastos) }\end{array}$ & Equinaza & Bovinaz & $\begin{array}{l}\text { Dry } \\
\text { grass }\end{array}$ & $\begin{array}{l}\text { Paper } \\
\text { pulp }\end{array}$ & $\begin{array}{l}\text { Chopped } \\
\text { cardboard }\end{array}$ \\
\hline Density (g/ cm3) & 0.18 & 0.11 & 0.10 & 0.15 & 0.24 & 0.04 & 0.46 & 0.32 \\
\hline pH & 4.7 & 4.54 & 4.94 & 7.94 & 8.91 & 7.16 & 7.55 & 7.36 \\
\hline C.E. $(\mathrm{dS} / \mathrm{m})$ & 0.37 & 0.39 & 0.60 & 8.71 & 0.40 & 0.72 & 1.03 & 1.97 \\
\hline Humidity \% & 80.34 & 83.57 & 89.57 & 64.17 & 42.72 & 6.76 & 59.51 & 66.77 \\
\hline Ashes\% & 2.88 & 1.53 & 1.69 & 4.77 & 19.08 & 10.72 & 20.69 & 12.40 \\
\hline Insoluble residue \% & 0.19 & 0.15 & 0.20 & 2.60 & 9.49 & 3.73 & 2.18 & 11.02 \\
\hline C.I.C. (meq/100g) & 15.71 & 17.33 & 17.12 & 54.40 & 80.76 & 168.69 & 26.61 & 23.53 \\
\hline Total nitrogen \% & 0.27 & 0.26 & 0.20 & 0.60 & 0.96 & 1.33 & 0.10 & 0.16 \\
\hline Total potassium\% & 0.45 & 0.62 & 0.35 & 0.28 & 2.21 & 2.20 & 0.009 & 0.02 \\
\hline Total calcium\% & 0.93 & 0.09 & 0.07 & 0.31 & 0.91 & 0.48 & 6.37 & 2.59 \\
\hline Total magnesium\% & 0.03 & 0.03 & 0.02 & 0.11 & 0.26 & 0.18 & 0.10 & 0.13 \\
\hline Total phosphorus\% & 0.03 & 0.04 & 0.03 & 0.15 & 0.26 & 0.21 & 0.018 & 0.02 \\
\hline Sulfur \% & 0.02 & 0.04 & 0.03 & 0.05 & 0.25 & 0.28 & 0.026 & 0.031 \\
\hline Sodium \% & 0.02 & 0.02 & 0.08 & 0.09 & 0.05 & 0.07 & 0.05 & 0.11 \\
\hline Organic carbon $\mathrm{O} \%$ & 6.67 & 5.72 & 3.67 & 12.61 & 16.55 & 31.52 & 8.37 & 8.81 \\
\hline $\mathrm{C} / \mathrm{N}$ ratio & 24.94 & 21.77 & 18.42 & 20.95 & 17.20 & 23.64 & 86.12 & 55.25 \\
\hline Moisture retention \% & 34.31 & 37.2 & 28.12 & 116.44 & 191.88 & 429.44 & 100.27 & 69.92 \\
\hline $\begin{array}{l}\text { Volatilization } \\
\text { losses \% }\end{array}$ & 16.78 & 14.90 & 8.74 & 31.06 & 38.20 & 82.52 & 19.80 & 20.83 \\
\hline Total Si\% & 0.09 & 0.06 & 0.09 & 0.97 & 2.89 & 1.61 & 0.59 & 1.29 \\
\hline
\end{tabular}

Taking into account the results of the laboratory analyzes (table 2) and using the Cornell University formula (Equation 1), to balance the carbon-nitrogen ratio in the mixtures, the formulations used in each cell were established.

Equation 1

$$
R=\frac{Q 1(C 1 \times(100-M 1))+Q 2(C 2 \times(100-M 2))+Q 3(C 3 \times(100-M 3)) \ldots}{Q 1(N 1 \times(100-M 1))+Q 2(N 2 \times(100-M 2))+Q 3(N 3 \times(100-M 3)) \ldots}
$$

The formula took into account for each raw material $(1,2,3$, etc.) the humidity $(M)$, carbon content $(C)$, nitrogen content $(N)$ and weight $(Q)$ as shown in table 2 . The values were balanced according to the carbon/nitrogen ratio $(\mathrm{C}: \mathrm{N})$, to reach a final ratio of 30 carbons for each nitrogen in the total mixture.

The treatment of the residues was worked through a composting system in aerobic piles, where the organic residues collected in the household collection routes were mixed with others to maintain a Carbon-Nitrogen ratio of 30/1, conical piles were made which reached $1.5 \mathrm{~m}$ in height, these piles were manually turned by the recyclers every third day, and parameters such as temperature, humidity and $\mathrm{pH}$ were monitored daily. The information records are consigned in formats diligent by recyclers for monitoring processes. In Figures 5, 6 and 7 can be seen organic waste collected in routes, setting piles composting and degradation process of waste through vermiculture technology. 
International Journal of Engineering Research and Technology. ISSN 0974-3154, Volume 13, Number 8 (2020), pp. 2067-2080

(C) International Research Publication House. https://dx.doi.org/10.37624/IJERT/13.8.2020.2067-2080

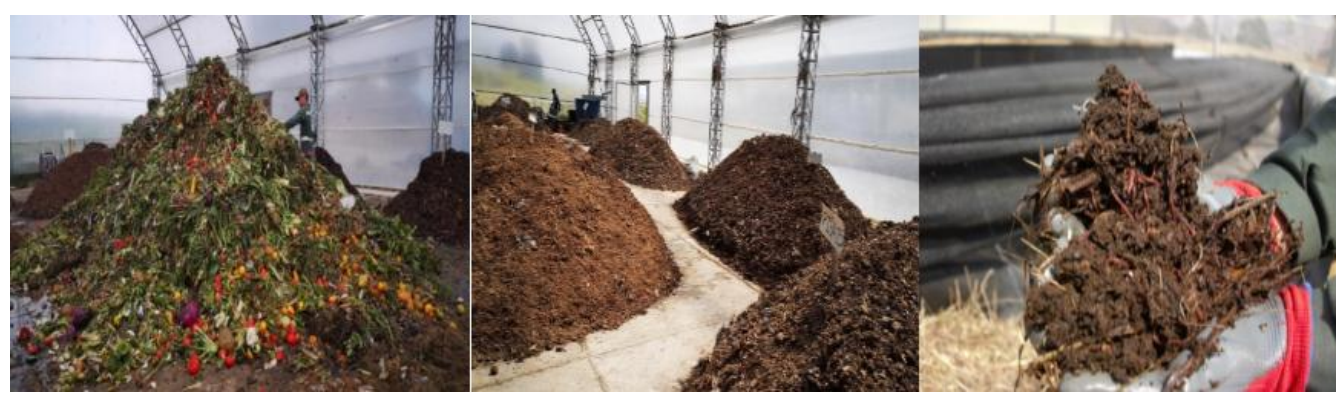

Figures 5, 6 and 7 correspond to the organic waste harvested, armed composting piles and degradation of waste by vermiculture.

\section{Vermiculture technology}

For the generation of vermicompost, part of the material degraded in the compost piles during 8 days of processing, was passed to vermiculture beds. To assemble these beds, $120 \mathrm{~kg}$ of Californian red worm calf (eisenia foetida) were added to two beds $1 \mathrm{~m}$ wide by $12 \mathrm{~m}$ long each. Before introducing the worms into the mixtures, feeding tests were performed, which corresponded to introducing 10 worms in $50 \mathrm{~g}$ of substrate for 24 hours. After this time, the response of the worms was analyzed (they adapted, escaped or died), for the particular case the worms adapted well to the substrate. For the calculation of the feeding frequency, it was taken into account that: 1,000 worms have the capacity to consume $1 \mathrm{~kg}$ of organic waste daily.

In total, 234 tons of organic solid waste were processed in the harvesting plant, coming from home collection routes, a route to a market place and inclusion of other organic waste generated in the study area. The evaluation period was of 7 months and weights were recorded at 75 routes of collection home as shown in Table 3 .

Table 3. Amounts of waste collected per route day in participating homes

\begin{tabular}{|c|c|c|c|c|c|}
\hline Route & Weight in $\mathrm{Kg}$ & Route & Weight in $\mathrm{Kg}$ & Route & Weight in $\mathrm{Kg}$ \\
\hline 1 & 301.8 & 26 & 415.8 & 51 & 269 \\
\hline 2 & 359.4 & 27 & 547.6 & 52 & 508.8 \\
\hline 3 & 348 & 28 & 415.2 & 53 & 366.8 \\
\hline 4 & 359.75 & 29 & 345.2 & 54 & 373.2 \\
\hline 5 & 298 & 30 & 755.2 & 55 & 457 \\
\hline 6 & 442 & 31 & 452.6 & 56 & 412 \\
\hline 7 & 367.8 & 32 & 556.6 & 57 & 380.6 \\
\hline 8 & 365 & 33 & 417 & 58 & 465.8 \\
\hline 9 & 462.8 & 3.4 & 440.2 & 59 & 369.4 \\
\hline 10 & 368.4 & 35 & 518.6 & 60 & 312.6 \\
\hline 11 & 362.9 & 36 & 425.8 & 61 & 484 \\
\hline 12 & 466 & 37 & 402 & 62 & 463.4 \\
\hline 13 & 554.4 & 38 & 500 & 63 & 352.8 \\
\hline 14 & 703 & 39 & 339.2 & 64 & 421.8 \\
\hline 15 & 469.6 & 40 & 540 & 65 & 434.4 \\
\hline 16 & 349 & 41 & 469.6 & 66 & 360.4 \\
\hline 17 & 403.2 & 42 & 472 & 67 & 568.6 \\
\hline 18 & 519 & 43 & 483.8 & 68 & 420.2 \\
\hline 19 & 515.2 & 44 & 402.4 & 69 & 426.2 \\
\hline 20 & 367.2 & 45 & 463.6 & 70 & 462.2 \\
\hline 21 & 555.4 & 46 & 446.6 & 71 & 353.6 \\
\hline 22 & 420.8 & 47 & 415 & 72 & 432 \\
\hline 23 & 299.2 & 48 & 333.2 & 73 & 522.4 \\
\hline 24 & 560.6 & 49 & 498.6 & 74 & 374.4 \\
\hline 25 & 351 & 50 & 416 & 75 & 400 \\
\hline \multicolumn{3}{|c|}{ Total } & \multicolumn{3}{|c|}{$30,608 \mathrm{~kg}$} \\
\hline
\end{tabular}


International Journal of Engineering Research and Technology. ISSN 0974-3154, Volume 13, Number 8 (2020), pp. 2067-2080

(C) International Research Publication House. https://dx.doi.org/10.37624/IJERT/13.8.2020.2067-2080

As shown in Table 3, the values of waste collection per day of collection were between 300 and $700 \mathrm{Kg}$, an average of weekly generation per route day of $1,392 \mathrm{Kg}$ was obtained, an average of daily collection of $464 \mathrm{~kg}$ per day route and an average of $2.32 \mathrm{~kg}$ of waste per each of the housing for collection day. Data can also be inferred, that each recycler collected on average $58 \mathrm{~kg}$ in two hours per day of collection.
Regarding the quantities collected in the home collection routes, it can be seen that the participation percentage was low, taking into account that 75 collection routes were carried out and a total of $30,608 \mathrm{~kg}$ was obtained, compared to receiving other organic waste as shown in graph 1.

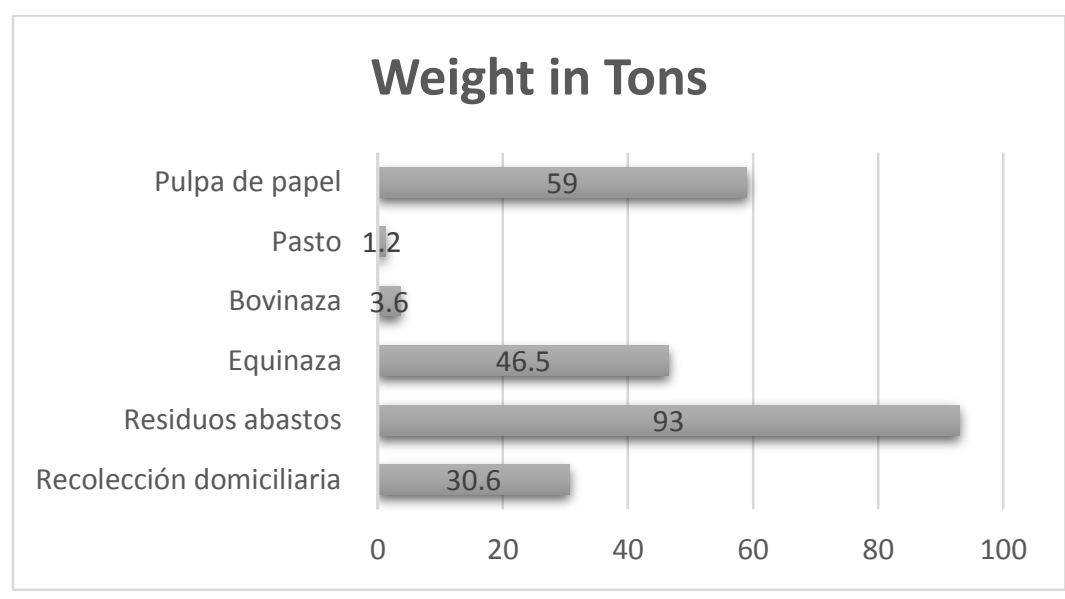

Graph 1. Total waste processed at the utilization plant.

In the graph it can be seen that the greater amounts as transformed corresponded to central de abastos residues, followed by the pulp and the equinaza. With the collected waste, 15 compost piles were formed, of which 5 managed to finish the degradation process to be characterized.

\section{Composting process evaluation}

To monitor the temperature and $\mathrm{pH}$ parameters in the composting piles, these parameters were monitored. Its behavior is shown in graphs 2 and 3 .

In the graph it can be seen that most of the piles were adjusted to a normal composting process with respect to the "Curve of stages of the composting process" (Campitelli, Ceppi, Rubenacker and Velasco, 2010), reaching temperatures between $22 \pm 2{ }^{\circ} \mathrm{C}$ and $60 \pm 2{ }^{\circ} \mathrm{C}$, reaching in most cases the thermophilic or sanitizing phase.

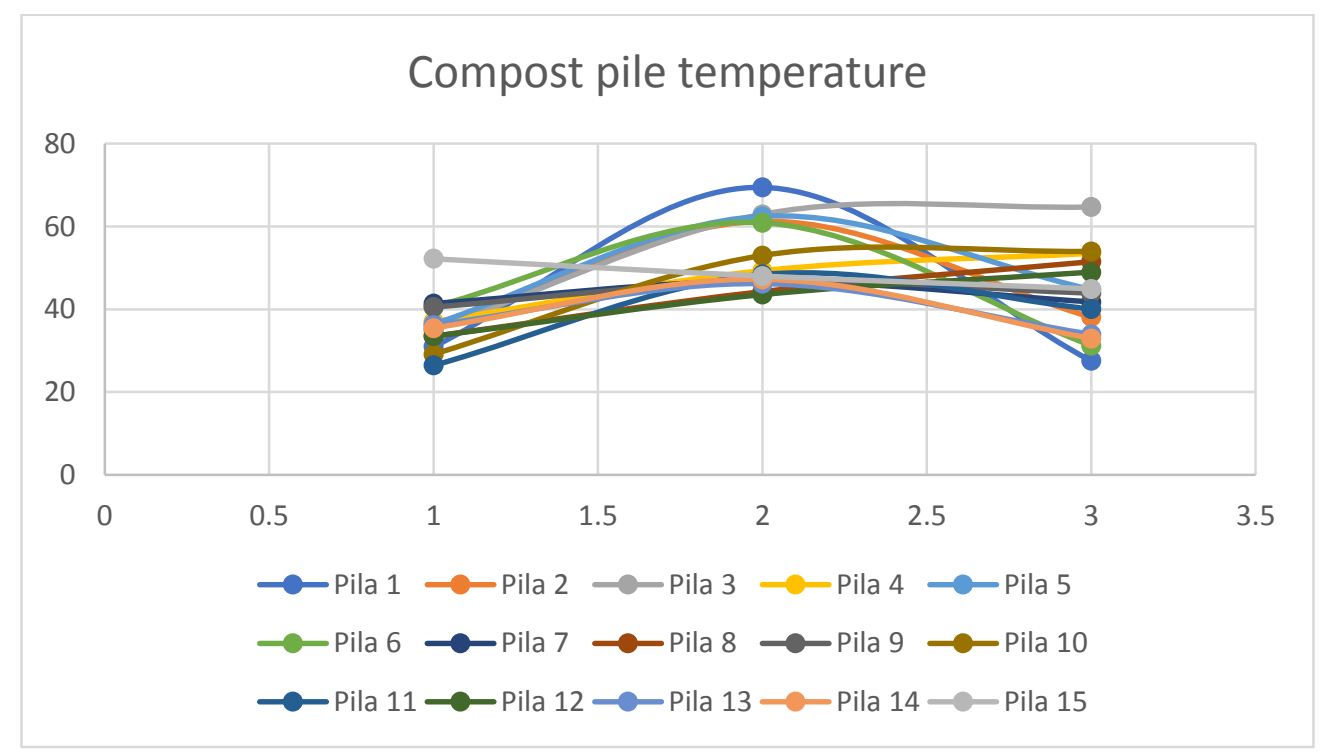

Graph 2. Temperature behavior in composting piles.

Source: own elaboration. 
International Journal of Engineering Research and Technology. ISSN 0974-3154, Volume 13, Number 8 (2020), pp. 2067-2080

(C) International Research Publication House. https://dx.doi.org/10.37624/IJERT/13.8.2020.2067-2080

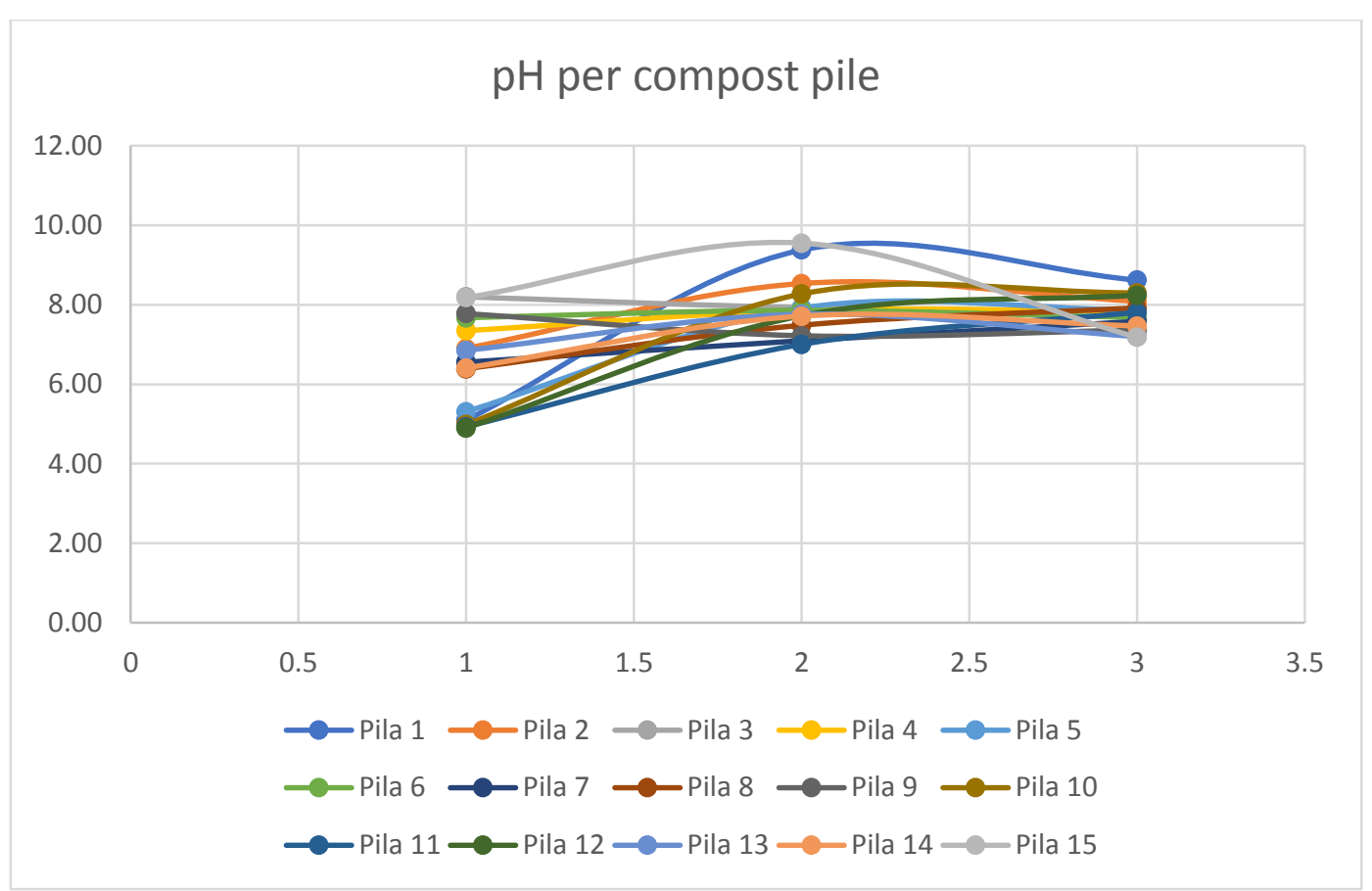

Graph 3. $\mathrm{pH}$ behavior in composting piles.

Source: own elaboration.

In the case of $\mathrm{pH}$, it can be seen that in the first stages of the degradation process a decrease occurs, which is a typical behavior generated in this technology, and due to the degradation mainly of carbohydrates and soluble compounds that cause organic acids to be produced therefore the $\mathrm{pH}$ drops. It can also be seen that most of the cells managed to stabilize until reaching $\mathrm{pH}$ measurements above 7 , which is one of the parameters for the product to be suitable for agriculture.

\section{Laboratory Analysis Results}

The Table 4 presented the results of laboratory tests of different cells formed in the utilization plant; These results were compared with the general requirements of NTC 5167 for organic products used as fertilizers and soil amendments in Colombia.

Table 4. Comparison of laboratory results vs parameters required in technical standard NTC 5167.

\begin{tabular}{|c|c|c|c|c|c|c|c|c|c|c|c|}
\hline $\begin{array}{c}\text { PARAMETERS TO } \\
\text { CHARACTERIZE } \\
\text { STANDARD NTC } 5167\end{array}$ & $\begin{array}{l}\text { PARAMETER } \\
\text { TO } \\
\text { GUARANTEE } \\
\text { NTC 5167 }\end{array}$ & $\begin{array}{c}\text { PILE } \\
2\end{array}$ & $\begin{array}{l}\text { Comply } \\
\text { NTC } \\
\text { (pile 2) }\end{array}$ & $\begin{array}{c}\text { PILE } \\
3\end{array}$ & $\begin{array}{l}\text { Comply } \\
\text { NTC } \\
\text { (pile 3) }\end{array}$ & $\begin{array}{c}\text { PILE } \\
5\end{array}$ & $\begin{array}{l}\text { Comply } \\
\text { NTC } \\
\text { (pile 5) }\end{array}$ & $\begin{array}{l}\text { PILE } \\
9\end{array}$ & $\begin{array}{l}\text { Comply } \\
\text { NTC } \\
\text { (pile 9) }\end{array}$ & $\begin{array}{l}\text { PILE } \\
14\end{array}$ & $\begin{array}{c}\text { Comply } \\
\text { NTC } \\
\text { (pile } \\
\text { 14) }\end{array}$ \\
\hline Volatilization losses\% & NA & 29.12 & NA & 21.85 & NA & 32.98 & NA & 19.00 & NA & 26.02 & NA \\
\hline Ash content & $<60 \%$ & 47.04 & YES & 43.29 & YES & 39.24 & YES & 39.25 & YES & 27.45 & YES \\
\hline Moisture content & $<35 \%$ & 23.84 & YES & 34.86 & YES & 27.78 & YES & 41.75 & NO & 46.53 & NO \\
\hline Oxidable organic carbon & $>15 \%$ & 12.12 & NO & 8.97 & NO & 12.88 & NO & 8.00 & NO & 10.68 & NO \\
\hline Nitrogen & NA & 1.22 & NA & 0.88 & NA & 1.21 & NA & 0.70 & NA & 0.68 & NA \\
\hline Phosphorus (P2O5) & NA & 0.21 & NA & 0.25 & NA & 0.28 & NA & 0.15 & NA & 0.16 & NA \\
\hline Potassium (K2O) & NA & 1.66 & NA & 0.88 & NA & 1.34 & NA & 0.70 & NA & 0.69 & NA \\
\hline $\mathrm{C} / \mathrm{N}$ ratio & NA & 9.95 & NA & 10.20 & NA & 10.68 & NA & 11.44 & NA & 15.60 & NA \\
\hline $\begin{array}{l}\text { CIC (cmol (+) Kg1) } \\
(\text { meq/100gr) }\end{array}$ & NA & 39.90 & NA & 31.09 & NA & 49.22 & NA & 31.89 & NA & 42.55 & NA \\
\hline $\begin{array}{l}\text { Moisture retention } \\
\text { capacity \% }\end{array}$ & NA & 102.71 & NA & 81.55 & NA & 112.46 & NA & 67.41 & NA & 93.41 & NA \\
\hline pH & $>4-<9$ & 8.34 & YES & 7.61 & YES & 7.86 & YES & 7.8 & YES & 7.83 & YES \\
\hline Density (gr/cm3) & $<0.6 \mathrm{~g} / \mathrm{cm} 3$ & 0.41 & YES & 0.50 & YES & 0.41 & YES & 0.52 & YES & 0.45 & YES \\
\hline
\end{tabular}

Note $*$ The spaces that appear with the expression Not Applicable (NA) are not a requirement of NTC 5167. 
International Journal of Engineering Research and Technology. ISSN 0974-3154, Volume 13, Number 8 (2020), pp. 2067-2080

(C) International Research Publication House. https://dx.doi.org/10.37624/IJERT/13.8.2020.2067-2080

In the comparison shown in table number 4 , it can be seen that for the oxidable organic carbon parameters, the fertilizers produced did not meet the reference values. It is noteworthy that the value for oxidable organic carbon from the initial characterization of the waste showed low values, which was reflected in the final results for this parameter. For the ash content, $\mathrm{pH}$ and density, all fertilizers met the reference value of the standard. For the moisture content parameter, it was high for cells 9 and 14 with respect to the value required by the standard, these results can be attributed to an error in taking the sample or not suspending irrigation at the time of taking the samples.

For the final carbon/nitrogen ratio and although the standard does not require it, the values were below carbon/nitrogen ratios $<20 / 1$, this indicates that the fertilizers were mature and ready for use as amendments in the recovery or restoration of degraded soils, as well as their use in agricultural and reforestation activities as basic sources of fertilization and load of microorganisms to the soil favoring the development of plant species.

\section{Collection routes evaluation}

A perception survey was carried out, both for users of the collection route and for the waste picker organization with which this was done, in order to evaluate the comprehensive management scheme for organic waste implemented. The user perception survey was carried out on 20 people for each neighborhood, for a total of 80 users; as well as all the personnel who carry out the collection and transport tasks by the waste pickers' organization. The results of the survey of the users of the collection route are shown in Table 5.

Table 5. Mochuelo Bajo users' opinion about the organic waste collection service.

\begin{tabular}{|c|c|c|c|c|c|}
\hline \multirow[t]{2}{*}{ Questions } & \multirow[t]{2}{*}{ Options } & \multicolumn{4}{|c|}{ Neighborhood } \\
\hline & & Lagunitas & Paticos & Barranquitos & La Esmeralda \\
\hline \multirow[t]{2}{*}{ Sex } & Woman & 15 & 12 & 18 & 17 \\
\hline & Man & 5 & 8 & 2 & 3 \\
\hline \multirow{3}{*}{$\begin{array}{l}\text { How did you perceive the } \\
\text { collection service by the } \\
\text { organization? }\end{array}$} & Good & 17 & 20 & 20 & 20 \\
\hline & Regular & 3 & 0 & 0 & 0 \\
\hline & Bad & 0 & 0 & 0 & 0 \\
\hline \multirow{2}{*}{$\begin{array}{l}\text { Do you think it is good that } \\
\text { this collection service was } \\
\text { presented in more places in } \\
\text { the city? }\end{array}$} & Yes & 20 & 20 & 20 & 20 \\
\hline & Not & 0 & 0 & 0 & 0 \\
\hline \multirow[t]{3}{*}{$\begin{array}{l}\text { What was most important to } \\
\text { you about this research? }\end{array}$} & $\begin{array}{l}\text { Organic waste stopped reaching the } \\
\text { landfill }\end{array}$ & 16 & 16 & 8 & 13 \\
\hline & $\begin{array}{l}\text { Feeling satisfied because you know it } \\
\text { helps the environment }\end{array}$ & 13 & 17 & 19 & 10 \\
\hline & $\begin{array}{l}\text { That a vulnerable population group was } \\
\text { favored }\end{array}$ & 10 & 12 & 8 & 9 \\
\hline \multirow{4}{*}{$\begin{array}{l}\text { What would you change to } \\
\text { the collection service? }\end{array}$} & The can & 2 & 2 & 0 & 1 \\
\hline & The waste pickers' attitude & 2 & 0 & 0 & 0 \\
\hline & The schedules & 0 & 2 & 1 & 1 \\
\hline & None & 16 & 16 & 19 & 18 \\
\hline \multirow{3}{*}{$\begin{array}{l}\text { As for the frequency of } \\
\text { collection would be fine }\end{array}$} & Increase them & 3 & 1 & 4 & 2 \\
\hline & Decrease them & 0 & 1 & 1 & 0 \\
\hline & Leave them the same & 17 & 18 & 15 & 18 \\
\hline
\end{tabular}

For this survey, $97 \%$ of people considered that the organic waste collection service seemed good to them, and $100 \%$ answered that this service should be replicated in all neighborhoods in the city. On the other hand, people answered that the most important research was the use of organic waste, because, with the decline in the arrival of the waste to the landfill, helps to the environment and also was favored an organization of recyclers belonging to the area.

$95 \%$ of the surveyed people considered that the organic waste collection service should not have any change. In general, the people who participated were satisfied with the work carried 
International Journal of Engineering Research and Technology. ISSN 0974-3154, Volume 13, Number 8 (2020), pp. 2067-2080

(C) International Research Publication House. https://dx.doi.org/10.37624/IJERT/13.8.2020.2067-2080

out by the waste pickers' organization. The results of the

organization's perceptions are shown in Table 6.

Table 6. Opinion of members of the waste pickers' organization on the implementation of the comprehensive management scheme.

\begin{tabular}{|c|c|c|c|c|}
\hline \multirow{2}{*}{$\begin{array}{l}\text { 1. How did you perceive the attitude } \\
\text { of users towards waste pickers? }\end{array}$} & \multicolumn{2}{|l|}{ Friendly } & Normal & Aggressive \\
\hline & \multicolumn{2}{|l|}{9} & 1 & 0 \\
\hline \multirow{2}{*}{$\begin{array}{l}\text { 2. What comments did you receive } \\
\text { from users about the collection } \\
\text { route? }\end{array}$} & \multicolumn{2}{|l|}{ Positive } & \multicolumn{2}{|l|}{ Negative } \\
\hline & \multicolumn{2}{|l|}{8} & \multicolumn{2}{|l|}{2} \\
\hline \multirow{2}{*}{$\begin{array}{l}\text { 3. Would it be good if this type of } \\
\text { collection was presented in other } \\
\text { places in Bogotá? }\end{array}$} & \multicolumn{2}{|l|}{ Yes } & \multicolumn{2}{|l|}{ Not } \\
\hline & \multicolumn{2}{|l|}{10} & \multicolumn{2}{|l|}{0} \\
\hline \multirow{2}{*}{$\begin{array}{l}\text { 4. What would you change to the } \\
\text { collection service? }\end{array}$} & The cans & 3 & Waste pickers' attitude & 0 \\
\hline & Schedule & 1 & None of the above & 6 \\
\hline \multirow[t]{3}{*}{$\begin{array}{l}\text { 5. What was the most important } \\
\text { thing for you about this project? }\end{array}$} & $\begin{array}{l}\text { Residues stopped } \\
\text { reaching the landfill }\end{array}$ & 0 & $\begin{array}{l}\text { Feeling good because it helped the } \\
\text { environment }\end{array}$ & 1 \\
\hline & $\begin{array}{l}\text { Economic recognition for } \\
\text { carrying out the activity }\end{array}$ & 0 & $\begin{array}{l}\text { Be an example in Bogotá in waste } \\
\text { management }\end{array}$ & 0 \\
\hline & \multicolumn{3}{|l|}{ All of the above } & 9 \\
\hline
\end{tabular}

\begin{tabular}{|c|c|c|c|c|}
\hline \multirow{3}{*}{$\begin{array}{l}\text { 6. As for the collection frequency, is } \\
\text { that okay? } \\
\text { 7. As for the cars to transport the } \\
\text { waste? }\end{array}$} & Increase them & Decrease them & \multicolumn{2}{|l|}{ Leave them the same } \\
\hline & $\underline{5}$ & $\underline{0}$ & \multicolumn{2}{|l|}{$\underline{5}$} \\
\hline & They are suitable & $\underline{5}$ & $\underline{\text { They are not suitable }}$ & $\underline{5}$ \\
\hline \multirow{2}{*}{$\begin{array}{l}\text { 8. The physical activity of } \\
\text { transporting the waste to the } \\
\text { recycling plant seems to you? }\end{array}$} & $\underline{\text { Soft }}$ & $\underline{\text { Normal }}$ & \multicolumn{2}{|l|}{ Heavy } \\
\hline & $\underline{0}$ & $\underline{3}$ & \multicolumn{2}{|l|}{$\underline{7}$} \\
\hline \multirow[t]{2}{*}{$\begin{array}{l}\text { 9. Regarding the collection times, } \\
\text { did you notice the beneficiaries? }\end{array}$} & $\begin{array}{l}\text { They are always in the } \\
\text { house }\end{array}$ & $\underline{4}$ & $\begin{array}{l}\text { They are almost always in the } \\
\text { house }\end{array}$ & $\underline{6}$ \\
\hline & $\begin{array}{l}\text { They were hardly in the } \\
\text { house }\end{array}$ & $\underline{0}$ & They were never in the house & $\underline{0}$ \\
\hline \multirow{2}{*}{$\begin{array}{l}\text { 10. Regarding the number of people } \\
\text { who made the collection route, do } \\
\text { you think that }\end{array}$} & \multicolumn{2}{|c|}{$\begin{array}{l}\text { It was sufficient and was in accordance with } \\
\text { the number of users }\end{array}$} & \multicolumn{2}{|c|}{$\begin{array}{l}\text { It was insufficient regarding the } \\
\underline{\text { number of users }}\end{array}$} \\
\hline & \multicolumn{2}{|l|}{$\underline{7}$} & \multicolumn{2}{|l|}{$\underline{3}$} \\
\hline \multirow{2}{*}{$\begin{array}{l}\text { 11. Regarding the payment you } \\
\text { received for carrying out the } \\
\text { activity, you }\end{array}$} & I would increase it & $\begin{array}{l}\text { I would leave it } \\
\text { the same }\end{array}$ & \multicolumn{2}{|l|}{ I would decrease it } \\
\hline & $\underline{9}$ & $\underline{1}$ & \multicolumn{2}{|l|}{$\underline{0}$} \\
\hline \multirow{2}{*}{$\begin{array}{l}\text { 12. Would you like to continue } \\
\text { participating in projects to use } \\
\text { organic waste? }\end{array}$} & \multicolumn{2}{|l|}{$\underline{\text { Yes }}$} & \multicolumn{2}{|l|}{$\underline{\text { No }}$} \\
\hline & \multicolumn{2}{|l|}{$\underline{10}$} & \multicolumn{2}{|l|}{$\underline{0}$} \\
\hline \multirow{2}{*}{$\begin{array}{l}\text { 13. Do you think that with this work } \\
\text { the work of the recycler is } \\
\text { dignified? }\end{array}$} & \multicolumn{2}{|l|}{$\underline{\text { Yes }}$} & \multicolumn{2}{|l|}{$\underline{\text { No }}$} \\
\hline & \multicolumn{2}{|l|}{$\underline{9}$} & \multicolumn{2}{|l|}{$\underline{1}$} \\
\hline
\end{tabular}


International Journal of Engineering Research and Technology. ISSN 0974-3154, Volume 13, Number 8 (2020), pp. 2067-2080

(C) International Research Publication House. https://dx.doi.org/10.37624/IJERT/13.8.2020.2067-2080

The results of the survey of perception of the organization of recyclers points rum that the treatment by users to recyclers was respectful, also noted that almost always users made positive comments on the route and felt that this type of experience should be replicated in other neighborhoods of the city.

According to the experience gained in developing the case study, recyclers mention rum some aspects to improve service, which are mentioned below: a greater number of cans to deliver to all users willing and able to participate; that the frequencies of the route are made on the days that the inorganic waste truck does not pass; that the container cars to transport the waste are made of resistant material and in accordance with the access roads of the neighborhoods where the service is to be provided; carry out permanent sensitizations so that users classify the waste correctly, and finally they mention that it is necessary that they be recognized a rate that is in accordance with their effort, which allows dignifying their work.

\section{DISCUSSION}

Regarding the operational component or the comprehensive management scheme, the waste picker organization was able to adequately carry out all the selective collection and transformation functions of the waste collected through composting and vermiculture systems. However, the greatest challenge for the implementation of this type of scheme is to generate a tariff framework that covers the costs of selective collection and the use of organic waste by waste picker organizations.

One of the main challenges in the proposed model consisted of the quantities to be collected of waste and its subsequent transformation in the utilization plant, since manual turning requires a demanding labor force. The option of mechanizing gives the opportunity to transform a greater volume of waste, but sacrifices the inclusion of recyclers in the model, therefore, it is necessary to delve into the profitability of the system without mechanization, but it must promote a rate recognition to achieve significant gains for waste picker organizations.

It is also noteworthy, the commitment of the waste pickers who participated in the waste pickers organization to carry out the collection route, since through the permanent training they provided to the people who carried out the separation at the source in the homes and commercial premises, managed to achieve in a short time an almost perfect separation of organic waste.

One of the main results was the cultural change of the inhabitants of the four quarters participants, who managed to transform their habits in terms of organic waste separation. This was evidenced with the committed participation of its inhabitants, who voluntarily separated their waste and delivered it to the recyclers association without any incentive in return.

\section{CONCLUSIONS}

With the generation of systems for the use of organic solid waste in Bogotá, it can help to reduce up to $50 \%$ in the weight of the waste that is deposited in the Bogotá landfill. This fact supposes the increase in the useful life of the sanitary landfill, greater ease in its operation, in addition to the environmental benefit and quality of life of the populations that live near this final disposal site.

Composting and vermiculture technologies were presented as viable and accessible alternatives for management by recyclers with low educational levels and organizational and administrative difficulties. This shows that this type of process, together with technical and institutional support, can be a viable alternative that involves more organizations of waste pickers, reduces the burial of organic waste in the landfill, reduces negative environmental impacts and generates income for vulnerable populations.

From the results obtained in the tests carried out in the compost piles and analyzing the laboratory results, it is concluded that, despite some inconveniences presented for the normal development of the process such as irregular turning, the unavailability of some residues, among others, fertilizers considered to be of good quality were obtained taking into account the requirements of NTC 5167 for organic fertilizers or amendments.

The specific recognition of the recycling population as part of the solution can be materialized in organizational and business promotion, as well as in adequate remuneration through a tariff framework that encourages the selective collection and treatment of organic waste, through the inclusion of these in the category of usable waste in the regulatory framework of the city.

The work of using organic waste expands the inclusion opportunities of waste picker organizations. Its inclusion can promote the generation of employment and with it the generation of economic income for vulnerable families. In addition, the inclusion of the community that separates organic waste at the source allows transforming values and generating cultural changes towards responsible consumption, based on initiatives that facilitate the use of waste.

Separation at the source of the waste quality is the first step for proper management of waste organic solids in the city like Bogota. Make a good design for selective collection, accompanied by a system of awareness and permanent citizenship support they are key to the implementation of a model for the use of sustainable waste that allows to link effectively to organizations recyclers city.

\section{ACKNOWLEDGMENT}

The authors thank the Francisco José de Caldas District University for the full support in the development of this research, this being a product generated from it. 
International Journal of Engineering Research and Technology. ISSN 0974-3154, Volume 13, Number 8 (2020), pp. 2067-2080

(C) International Research Publication House. https://dx.doi.org/10.37624/IJERT/13.8.2020.2067-2080

\section{REFERENCES}

[1] Alianza Nacional para el Reciclaje Inclusivo. (2017). Guía para el fortalecimiento de Organizaciones de Recicladores, 36.

[2] Ariza, N. S. F. (2016). Manejo y separación de residuos sólidos urbanos. Análisis comparativo entre Madrid (España) y el distrito especial industrial y portuario de Barranquilla (Colombia)/Management and separation of urban solid waste comparative analysis between Madrid (Spain) and the industrial and port special district of Barranquilla (Colombia). Observatorio Medioambiental, 19, 197.

[3] Asociación Interamericana de Ingeniería Sanitaria y Ambiental-AIDIS; Centro Internacional de Investigaciones para el Desarrollo-IDRC (2006). Directrices para la gestión integrada y sostenible de residuos sólidos urbanos en américa latina y el caribe. Sao Paulo: AIDIS-IDRC.

[4] Bodova, E. (2017). Tools of environmental management and EU circular economy. MM Science Journal, 1, 17001706.

[5] Castells, X. E. (2005). Tratamiento y valorización energética de residuos. Ediciones Díaz de Santos.

[6] Castro, F. (2012). Informe" Caracterización de la población recicladora de oficio en Bogotá. Bogota: Uaesp.

[7] Cohen, P., Ijgosse, J., y Sturzenegger, G. (2013). Desarrollo de planes de inclusión para recicladores informales en sitios de disposición final: una guía operativa. IDB/IRR.

[8] Consorcio NCU. (2017). Estudio técnico de la caracterización en la fuente de residuos sólidos generados en la Ciudad de Bogotá. Bogotá

[9] Corredor, M. (2010). El Sector Reciclaje en Bogotá y su Región: Oportunidades para los Negocios Inclusivos. Guia Sectorial FUNDES, 2, 60.

[10] Cortés, H. G., \& Peña, J. I. (2014). Modelo de desarrollo sustentable para su implementación en políticas y proyectos. Rev.Esc.Adm.Neg., Enero-Juni(78), 40-55. https://doi.org/10.21158/01208160.n78.2015.1189

[11] Dourojeanni, A. (2000). Procedimientos de gestión para el desarrollo sustentable.

[12] Edalatpour, M. A., Mirzapour Al-e-hashem, S. M. J., Karimi, B., \& Bahli, B. (2018). Investigation on a novel sustainable model for waste management in megacities: A case study in tehran municipality. Sustainable cities and society, 36, 286-301.

[13] Field, C. B., MacCracken, S., Mastrandrea, M. D., Levy, A. N., Bilir, T. E., Barros, V. R., ... \& Moreno, J. M. (2014). Cambio climático 2014 Impactos, adaptación y vulnerabilidad.

[14] Gallopin, G. (2008). Medio Ambiente Y Desarrollo.
[15] Garnett, K., Cooper, T., Longhurst, P., Jude, S., \& Tyrrel, S. (2017). A conceptual framework for negotiating public involvement in municipal waste management decisionmaking in the UK. Waste Management, 66, 210-221.

[16] Giinther, R., Maria, W., Grimberg, E., \& Ubal, W. (2006). Directrices para la gestión integrada y sostenible de residuos sólidos urbanos en America Latina y el Caribe.

[17] Graziani, P. (2018). Economía circular e innovación tecnológica en residuos sólidos Oportunidades en América Latina.

[18] Hénault-Ethier, L., Martin, J. P., \& Housset, J. (2017). A dynamic model for organic waste management in Quebec (D-MOWIQ) as a tool to review environmental, societal and economic perspectives of a waste management policy. Waste Management, 66, 196-209.

[19] Marconatto, D. A. B., Barin-Cruz, L., Pozzebon, M., \& Poitras, J. E. (2016). Developing sustainable business models within BOP contexts: mobilizing native capability to cope with government programs. Journal of cleaner production, 129, 735-748.

[20] Marino, A. L., Chaves, G. D. L. D., \& dos Santos Junior, J. L. (2018). Do Brazilian municipalities have the technical capacity to implement solid waste management at the local level?. Journal of Cleaner Production, 188, 378-386.

[21] Medina, M. (1999). Reciclaje de desechos sólidos en América Latina. Frontera Norte, 11(21), 1-25.

[22] Mmaya, Vapsb, \& Dggirs. (2013). Guia para el aprovechamiento de residuos solidos organicos mediante compostaje y lombricultura. Ministerio de Medio Ambiente y Agua, primera ed(Bolivia).

[23] Lamboglia, R., Fiorentino, R., Mancini, D., \& Garzella, S. (2018). From a garbage crisis to sustainability strategies: The case study of Naples' waste collection firm. Journal of Cleaner Production, 186, 726-735.

[24] Lett, L. A. (2014). Las amenazas globales, el reciclaje de residuos y el concepto de economía circular. Revista argentina de microbiología, 46(1), 1-2.

[25] Lizaga, C. A. (2015). Economía Solidaria. Creative Commons Reconocimiento, 1-8.

[26] Pacheco, J. F., \& Contreras, E. (2016). Guía general para la gestión de residuos sólidos domiciliarios, 211.

[27] Padilla, A. J., \& Trujillo, J. C. (2018). Waste disposal and households' heterogeneity. Identifying factors shaping attitudes towards source-separated recycling in Bogotá, Colombia. Waste Management, 74, 16-33.

[28] Real Ferrer, G. (2016). Residuos y Sostenibilidad. El Modelo Europeo. La opción por la termovalorización, 29.

[29] Rebehy, P. C. P. W., Costa, A. L., Campello, C. A., de Freitas Espinoza, D., \& Neto, M. J. (2017). Innovative social business of selective waste collection in Brazil: Cleaner production and poverty reduction. Journal of 
International Journal of Engineering Research and Technology. ISSN 0974-3154, Volume 13, Number 8 (2020), pp. 2067-2080

(C) International Research Publication House. https://dx.doi.org/10.37624/IJERT/13.8.2020.2067-2080

Cleaner Production, 154, 462-473.

[30] Rodrigues, A. P., Fernandes, M. L., Rodrigues, M. F. F., Bortoluzzi, S. C., da Costa, S. G., \& de Lima, E. P. (2018). Developing criteria for performance assessment in municipal solid waste management. Journal of Cleaner Production, 186, 748-757.

[31] Rojas C, A., Yabar, H., Mizunoya, T., \& Higano, Y. (2018). The Potential Benefits of Introducing Informal Recyclers and Organic Waste Recovery to a Current Waste Management System: The Case Study of Santiago de Chile. Resources, 7(1), 18.

[32] Sáez, A., \& Urdaneta, J. A. (2014). Manejo de residuos sólidos en América Latina y el Caribe. Omnia Año, 20(3), 121-135.

[33] Santos Calderon, J. M., Mendoza Daza, J. M., López Murcia, J. D., Sierra Botero, M. E., \& Lozano Fonseca, A. (2016). Superintendencia de Servicios Públicos Domiciliarios: Informe Nacional de Aprovechamiento 2016, 1, 72 .

[34] Schamber, P. (2017). " Avances y desafíos para el reciclaje inclusivo: evaluación de 12 ciudades de América Latina y el Caribe".: The Economist Intelligence Unit (EIU), 2017, Nueva York. Estudios Socioterritoriales, 22, 0-0.

[35] Stephen, J. L., \& Periyasamy, B. (2018). Innovative developments in biofuels production from organic waste materials: A review. Fuel, 214, 623-633.

[36] Six, L., Velghe, F., Verstichel, S., \& De Meester, S. (2016). Sustainability considerations on the valorization of organic waste. In Biotransformation of agricultural waste and by-products(pp. 287-307).

[37] Oliveira, L. S., Oliveira, D. S., Bezerra, B. S., Pereira, B. S., \& Battistelle, R. A. G. (2017). Environmental analysis of organic waste treatment focusing on composting scenarios. Journal of cleaner production, 155, 229-237.

[38] Terraza, H. (2009). Lineamientos estratégicos del Banco Interamericano de Desarrollo para el sector de residuos sólidos. Banco Interamericano de Desarrollo. Washington (USA).

[39] Wan, C., Shen, G. Q., \& Choi, S. (2018). Differential public support for waste management policy: The case of Hong Kong. Journal of Cleaner Production, 175, 477488.

[40] Bohórquez, W. (2019). El proceso de compostaje. Bogotá, Colombia. Universidad la Salle. Libro en línea. Recuperado de: https://ciencia.lasalle.edu.co/cgi/viewcontent.cgi?article $=1071 \&$ context $=$ libros

[41] Cunha, D., Pardo, J. E., Álvarez-Ortí, M. y PardoGiménez, A. (2018). Desarrollo del cultivo de Agaricus bisporus en Brasil: suplementación del compost y utilización de híbridos. Revista Ciência Agronômica, 49(1), 122-129. Recuperado de: http://ccarevista.ufc.br/seer/index.php/ccarevista/article/ view/4129

[42] Delgado, M., Mendoza, K., González, M., Tadeo, J. y Martín, J. (2019). Evaluación del proceso de compostaje de residuos avícolas empleando diferentes mezclas de sustratos. Revista Internacional de Contaminación Ambiental, 35(4), 965-977. Recuperado de: https://www.revistascca.unam.mx/rica/index.php/rica/art icle/view/RICA.2019.35.04.15

[43] El Tiempo (29 de abril de 2020). Vea en fotos cómo es la emergencia del relleno sanitario Doña Juana. El tiempo. Recuperado de: https://www.eltiempo.com/bogota /relleno-dona-juana-fotos-de-emergencia-por-underrumbe-de-basura-489940

[44] Faundez, F. (2011). La Pintana: iniciativas para una comuna más sustentable. Recuperado de: http://www.plataformaurbana.cl/archive/2011/08/12/lapintana-iniciativas-para-una-comuna-mas-sustentable/

[45] Íñiguez, G., Rodríguez, R. y Virgen, G. (2005). Utilización de supbroductos de la industria tequilera. Parte 7. Compostaje de bagazo de agave y vinazas tequileras. Revista internacional de contaminación ambiental, 21(1), 37-50. Recuperado de: https://www.revistascca.unam.mx/rica/index.php/rica/art icle/view/22570

[46] Jaramillo Henao, G. Zapata Márquez, L. M. (2008). Aprovechamiento de los residuos sólidos orgánicos en Colombia. Recuperado de: http://bibliotecadigital. udea.edu.co/dspace/bitstream/10495/45/1/Aprovechamie ntoRSOUenColombia.pdf

[47] López, S., Serrato, R., Castelán, O. y Avilés, F. (2018). Comparación entre dos métodos de ventilación en la composición química de compost de estiércoles pecuarios. Revista internacional de contaminación ambiental, 34(2), 263-271. https://www.revistascca. unam.mx/rica/index.php/rica/article/view/RICA.2018.34 $.02 .07 / 46755$

[48] Organización Panamericana de la Salud, OPS en conjunto con el Banco Interamericano de Desarrollo (BID), la Asociación Interamericana de Ingeniería Sanitaria y los gobiernos de los países intervinientes de América Latina (2010). Informe de la Evaluación Regional del manejo de residuos sólidos urbanos en América Latina y el Caribe (2010). Recuperado de: https://publications.iadb.org/ publications/spanish/document/Informe-de-laevaluaci\%C3\%B3n-regional-del-manejo-de-residuoss\%C3\%B3lidos-urbanos-en-Am\%C3\%A9rica-Latina-yel-Caribe-2010.pdf

[49] Oviedo, E., Marmolejo, L. y Torres, P. (2014). Influencia de la frecuencia de volteo para el control de la humedad de los sustratos en el compostaje de biorresiduos de origen municipal. Revista internacional de contaminación ambiental, 30(1), 91-100. Recuperado de: https://www.revistascca.unam.mx/rica/index.php/rica/art icle/view/35074/40216

[50] Penagos, W., Adarraga, J., Aguas, D. y Molina, E. (2011). 
International Journal of Engineering Research and Technology. ISSN 0974-3154, Volume 13, Number 8 (2020), pp. 2067-2080

(C) International Research Publication House. https://dx.doi.org/10.37624/IJERT/13.8.2020.2067-2080

Reducción de los residuos sólidos orgánicos en Colombia por medio del compostaje líquido. Revista Ingeniare, (11). Recuperado de: http://ojsinvestigacion. unilibrebaq.edu.co/ojsinvestigacion/index.php/ingeniare/ article/view/346/336

[51] Quintero, D. (2016). El papel de la gestión territorial en la ubicación de rellenos sanitarios. Caso de estudio: relleno sanitario Doña Juana, Bogotá, Colombia. Perspectiva Geográfica, 21(2), 251-276. DOI: https://doi.org/10.19053/01233769.5852

[52] Román, P., Martínez, M. M. y Pantoja, A. (2013). Manual de compostaje del agricultor: Experiencias en América Latina. Recuperado de: http://www.fao.org/3/ai3388s.pdf

[53] Suarez, J. (2012). Aprovechamiento de los residuos sólidos provenientes del beneficio del café, en el municipio de Betania Antioquía: Usos y aplicaciones. Trabajo de grado Especialista en Gestión Integral de Residuos Sólidos y Peligrosos. Caldas-Colombia. Corporación universitaria Lasallista. Recuperado de: http://repository.lasallista.edu.co/dspace/bitstream/1056 7/627/1/APROVECHAMIENTO_RESIDUOS_SOLID OS_BENEFICIO_CAFE.pdf

[54] Unidad Administrativa Especial de Servicios Públicos, UAESP. (2020). Especiales UAESP Relleno Sanitario Doña Juana. Recuperado de: http://www.uaesp.gov.co /especiales/relleno/ 